\title{
PROGRESSIVE MUSCULAR DYSTROPHY AND TYMPANIC MUSCLE REFLEX
}

\author{
KEIZO MASUDA, M. D. \\ Hara National Sanatorium, Hiroshima \\ YASUO HARADA, M. D. \\ Department of Otolaryngology, Hiroshima University School of Medicine, Hiroshima
}

1) Patients with Duchenne type of progressive muscular dystrophy were tested by audiometer and the reflex of tympanic muscles was measured with an impedance audiometer. The pathological changes of the tympanic muscles were examined by $\mathrm{HE}$ staining

2) Duchenne type patients' audiograms showed a slight hearing loss in low tones, but there was none in the controls. We found this tendency increasingly in the older patients.

3) The latency and the time to reach the top in the middle ear muscle reflex did not differ very much between Duchenne type and the controls, but after the sound reflex ceased, the time to return to the basal line prolonged in the Duchenne type. This tendency increased as the patients were older.

4) The morphological changes in the tympanic muscles of Duchenne type patients were not so severe as compared with other parts of skeleton muscles.

5) Discussions were made on the above mentioned results in relation to the tympanic muscles and low tone hearing loss. It is a conclusion that the test of the tympanic muscle reflex in the patients with progressive muscular dystrophy can be a new method to determine the progressiveness of muscular dystrophy.

$\mathrm{A} 82-0175-22522$

\section{進行性筋ジストロフィー症と耳小骨筋反射}

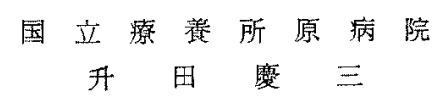

玄島大学医学部耳鼻毗喉科学教室

原四康类

\section{緒言}

耳小骨筋は音響性の刺激に上り反射性に収綃する中耳 腔内に存在する横紋筋で，鼓膜张筋と鐙骨筋上り成る が，その生理学的意義に関しては古くから論争の続いて いる所である。

彷って，進行性筋ジストロフィ一症（以下D. M.P. と 略す）の患者に招ける耳小骨筇反射の検討は，この閭题 の解決に一つのヒントを与文得省のでないかと荐兑
た. 更に， D.M.P. という疾病の本態の解明に，その 㭧者の全身横紋筋の生理学的, 病理学的な㛟討が数多く なされている、し加し作占比較的梌索の容易广近住筋飞 おいては，早期より、ジストロフィ一病変の進行が落明 でその検討飞蜼䍇する。

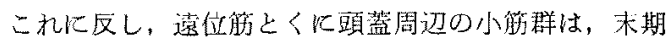
迄，此較的よく筋線維加保たれている。これら小筋群の

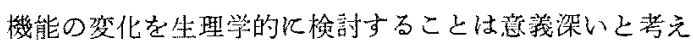


るが，特に耳小骴筋飞标いては，その音智性反射の発生 は，患者の意志飞加わりなく起り，全く他觉的飞その 变化を追求出来る点任注目した。

そこで著者らは，国立㙩龊所原病院人院中のD.M.P. 患者につき，オージオメータによる聴力検查を施行した

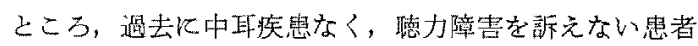

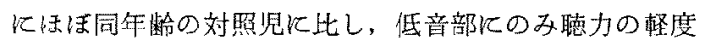
の損失を示寸者が多加った。

著者らはこの事実を，中耳伝音機權の中， D.M.P.忠 者の場合に侵されると考元られる耳小骨筋との関連にお いて追求して見た.

更飞, D. M.P. 剖検例飞括いて，耳小骨筋を病理組織 学的に検索したのでこれらの所見を併せて報告する。

\section{実 跧 方 法}

対象患者は国立療養所原病院入院中の D. M.P. Duchenne 型患者の中, 中耳疾患の既往のない者 45 名 選儿だ．正常対照例としては，耳科的に異常のない当院 入院中の一般慢性小児疾患々者括よび勤務職員をこれに あてた。

1）聴力検查はトリオ,オージオメーターモデル AS 19 を用い,トリオ聴力桧查室モデル MS206防音室内に 抬いて施行した。

D. M.P. 患者は自力で押しボタンを押すのが困難なも のが多いため, 介助者がボタンを握り，㭧者は指で介助 者の手飞触れ, 同時に介助者がボタンを押して信号を送 ると云う方法をとった，対照例はすべて，通常の方法に よった. 全員気導执よび骨導检查を施行した。

2）耳小骨筋反射は，インピーダンス法1飞より, Grason-Stadtler 社製 $1720 \mathrm{~B}$ オトアドミタンスメータ 一を用いた、刺激音としては，最高 $90 \mathrm{~dB}$ のオージオメ ータによる紨音を用いた。

はじめ片耳に刺激音を与光，耳小骨筋反射の出現す る最小の刺激音で閜值を測定し．次にこれより $10 \mathrm{~dB}$ 強 い音でこの反射を起させ．紙送り式レコーダーに描記し た.

刺激音は $500 \mathrm{~Hz}, 1 \mathrm{kHz}, 2 \mathrm{kHz}, 4 \mathrm{kHz}$ 学用い，それぞ れについて，はじめ10秒間，ついで 3 秒間の休息を和い て3秒間宛の刺激を10回加克, 10秒休息後, 最後汇10秒 間の刺激を加点て片耳の検查を終り，ついで反対耳にす 同様の検查を行った。

哔記した耳小骨筇反射のバターンは図1のごとくで， 刺激開始上り反射の出現迄の潜時, 反射出現上り振幅が

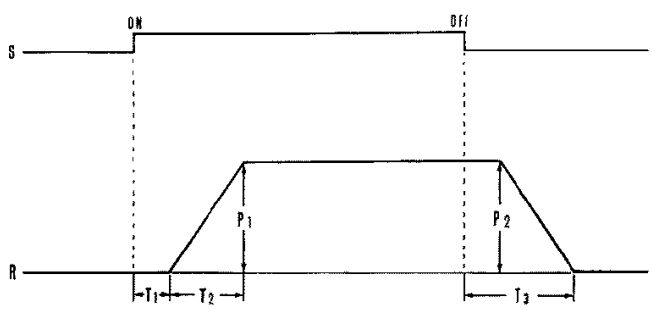

図 1 耳小管䈤反射の正常パターン

最高炕達する迄の時間, 刺激の反復による反射パターン の变化, 刺激終了より耳小骨筋が完全にはじめの位置に 復する迄の時間を測定した。

3）耳小骨笳の病理組織学的检索

D. M.P. Duchenne 型剖検例 4 例, 先天型 1 例 計 5 例飞ついて開頭, 脳摘出後, 頭蓋底錐体部飞電気鋸を入 れ，側頭骨錐体部を外耳，中耳势含めて摘出し，直ち に10\%ホルマリンに固定後, 鐙骨筋怙よび鼓膜張筋を摘 出し, 標本を作製した。

\section{成 繢}

I D. M.P. Duchenne 型恥力検査成績

表1のごとく, 縦軸偪力損出の程度, 横軸に周波数 をとり，各々の周波数汇拈ける聴力損失を示した者の人 数を枅目内汇部入した。

$250 \mathrm{~Hz}, 500 \mathrm{~Hz}$ K拈讨る $15 \mathrm{db}$ 以上の聴力損失を示す 者の数は, D. M.P. 45名中, $250 \mathrm{~Hz}$ で, 両耳 14 名, 右 だけ 3 名, 左だけ10名, $500 \mathrm{~Hz}$ で両耳 4 名, 右耳 4 名, 左耳6名で，これ対し，正常対照例は12名中， $250 \mathrm{~Hz}$ で左耳1名, $500 \mathrm{~Hz}$ では 0名と明加飞 D. M.P. 群化低 音域に和ける聴力損失者が多い。

この変化の出現の年齢別の分布では，表 2 の如く，年 齡の上昇と共に， $250 \mathrm{~Hz}, 500 \mathrm{~Hz}$ の聴力損失者の出現が 增加する。

II D. M.P. Duchenne 型耳小骨筋反射

耳小骨筋反射の出現は， D. M.P. Duchenne 型飞打 いて, 右耳て $1 \mathrm{kHz}, 90 \mathrm{db}$ 以内で, D. M. P. 45名中 42 名 $93.3 \%$ と高率飞検出し得たが, 他の周波数では, そ の出現にはかなりのばらつきが見られた。

今回は，両耳の $1 \mathrm{kHz}$ 亿括ける耳小骨反射の記録につ き, 年齢別に 3 群飞分けて検尌した.

第 1 群は 8 12 歳迄 15名, 第2 群は 13 16 藏迄 15 
表 1 D. M.P. Duchenne 型患者の聼力 右 迷

\begin{tabular}{|c|c|c|c|c|c|c|c|}
\hline $\mathrm{db} \quad \mathrm{Hz}$ & 125 & 250 & $0.5 \mathrm{k}$ & $1 \mathrm{k}$ & $2 \mathrm{k}$ & $4 \mathrm{k}$ & $8 \mathrm{k}$ \\
\hline-5 & 5 & 9 & 16 & 14 & 14 & 13 & 20 \\
\hline 0 & 6 & 13 & 11 & 13 & 20 & 15 & 15 \\
\hline+5 & 8 & 10 & 14 & 13 & 9 & 13 & 5 \\
\hline+10 & 10 & 1 & 4 & 3 & 0 & 3 & 1 \\
\hline+15 & 7 & 7 & & 1 & 2 & 1 & 3 \\
\hline+20 & 3 & & & 1 & & & 1 \\
\hline+25 & 6 & & & & & & \\
\hline+30 & & & & & & & \\
\hline
\end{tabular}

\begin{tabular}{rrrrrrrr} 
左 \\
db $\mathrm{dz}$ & 125 & 250 & $0.5 \mathrm{k}$ & $1 \mathrm{k}$ & $2 \mathrm{k}$ & $4 \mathrm{k}$ & $8 \mathrm{k}$ \\
\hline-5 & 5 & 11 & 13 & 12 & 20 & 13 & 20 \\
0 & 6 & 12 & 17 & 14 & 11 & 16 & 11 \\
+5 & 9 & 9 & 10 & 10 & 11 & 11 & 8 \\
+10 & 4 & 5 & 1 & 5 & 1 & 1 & 0 \\
+15 & 10 & 6 & 4 & 3 & 2 & 3 & 2 \\
+20 & 5 & 1 & & 1 & & 1 & 0 \\
+25 & 6 & 1 & & & & & 2 \\
+30 & & & & & & & 2
\end{tabular}

表 2 D.M.P.患者の年齢之聴力 有 耳

\begin{tabular}{|c|c|c|c|c|c|}
\hline & & 例 数 & 年 & $125 \mathrm{~Hz}$ & $150 \mathrm{db}$ 以上 $\downarrow$ \\
\hline Control & & 12 & $15 \sim 25$ 藏 & & 0 \\
\hline \multirow[t]{3}{*}{ D.M.P. } & 整 狱 & 14 & 12 歳以下 & & 2 \\
\hline & 中等症 & 14 & $13 \sim 16$ 藏 & & 0 \\
\hline & 重 症 & 14 & $16 \sim 24$ 歳 & & 9 \\
\hline \multicolumn{6}{|c|}{ 左 具 } \\
\hline \multicolumn{2}{|l|}{ Control } & 12 & $15 \sim 25$ 藏 & & 1 \\
\hline \multirow[t]{3}{*}{ D.M.P. } & 㪕 症定 & 14 & 12 藏以下 & & 3 \\
\hline & 中等諚 & 14 & $13 \sim 16$ 歳 & & 4 \\
\hline & 重 症 & 14 & $16 \sim 24$ 胔 & & 11 \\
\hline
\end{tabular}

名, 第 3 群は 17〜25歳迄 16名亡した. D.M.P. Duchenne 型の横敉䈤の変性消失の程度は進行性であり， 臨症症状加らして，大体年龄に比例して変化学示与と考

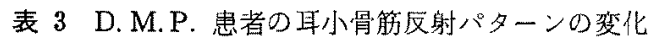
右耳

\begin{tabular}{lcccc}
\hline \multicolumn{1}{c}{$1 \mathrm{kHz}$} & & $\mathrm{T}_{1} \mathrm{msec}$ & $\mathrm{T}_{2} \mathrm{msec}$ & $\mathrm{T}_{3} \mathrm{msec}$ \\
\hline Control & 12 & 347.2 & 384.4 & 496.4 \\
D.M.P. 哫症 & 14 & 387.2 & 378.8 & 594.0 \\
中等症 & 14 & 322.0 & 388.8 & 601.2 \\
$\quad$ 重 症 & 15 & 357.6 & 394.8 & 988.8
\end{tabular}

左耳

\begin{tabular}{|c|c|c|c|c|}
\hline $1 \mathrm{kHz}$ & & $\mathrm{T}_{1} \mathrm{msec}$ & $\mathrm{T}_{2} \mathrm{msec}$ & $\mathrm{T}_{3} \mathrm{msec}$ \\
\hline Control & 10 & 354.4 & 388.4 & 470.0 \\
\hline D.M.P，埾憔 & 13 & 354.4 & 347.2 & 530.6 \\
\hline 中等症 & 13 & 322.0 & 396.8 & 587.6 \\
\hline 重 症䇥 & 11 & 357.6 & 346.4 & 1141.2 \\
\hline
\end{tabular}

えられるため，第1群は怪症群飞当り，第 2 群は中等症 群，第 3 群は重症群と考えてよいであるう。

表 3 は夫々第 1 群（怪症群），第 2 群（中等症群），第 3 群（重症群）の各耳に和ける潜時 $T_{1}$, 反射がはじまっ てから，最高汇達する迄の時間 $\mathrm{T}_{\mathrm{g}}$ ，刺激が終ってから

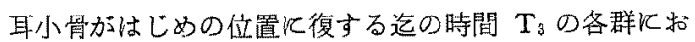
ける平均值である。

$\mathrm{T}_{1}, \mathrm{~T}_{2}$ では各群の間に特飞著明な変化は見られない が、, $T_{3}$ で，第 3 群汇批いて，第1群上り時間の延長加 明らか比熟められる。第2 群仕雨者の中間の值を示し た.

耳小具筋の疲学による反射振幅の变化については，今 回は刺激の反復が少なかったためか，各群關估明な差 異老認めなかった。

III D.M.P. 耳小筋の病理組織学的検索

今回検案し得た D.M.P. Duchenne 型 4例, 先天型 1 例の耳小祭筇の病理組織学的所見を通覽すると，Dechenne 型飞招いては，鐙骨筋，鼓膜張筋共飞他の部位 の骨格筋之同様，節線維の大小不同，变性消失，筋䩓核 の增加と中心移動，結合織就よび旨肪組織の增吅を認め る.しかし乍ら，支の程度は各症列飞より差があり，箱 線維も殆んど正常化近小所見を示柽度のあのから，筋 楾維の大半が变性，消失したもの迄ある。特に鐙骨觔で は，筋線維の数怔よび大きさも，鼓膜張筋に比し小さ いが病理組織学的所見では，病变の程度は大体平行して いる，各症例間でむかなりの差が譛められる先天型にお いては，Duchenne 型と同様の所見を認めるが，その病 


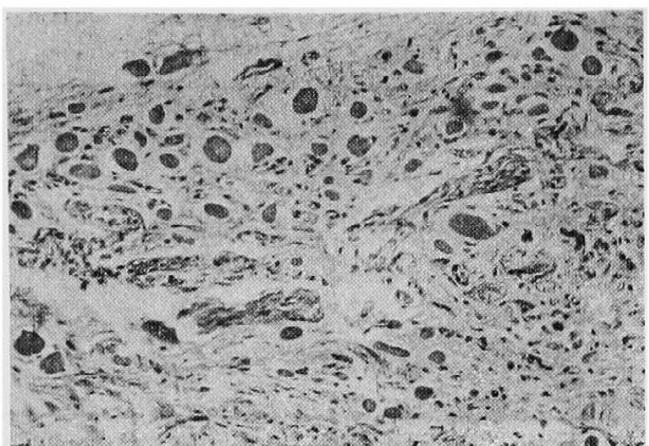

図 2 呈示した症例の鐙骨筋 筋線維の変性消失と結合織の増加はかなり著 明で，残存した筋線維は肥大を示すものがある。

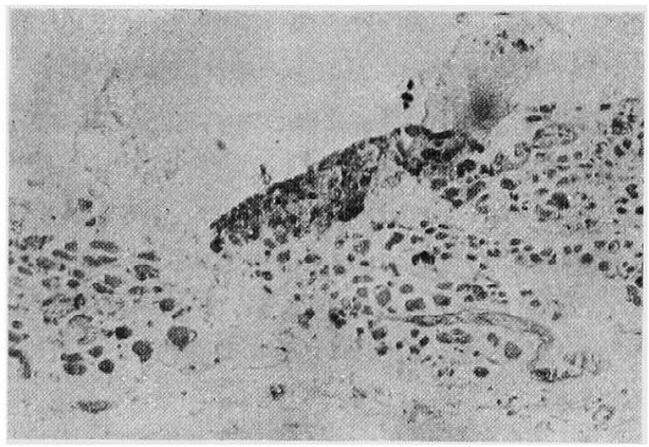

図 3 正常者の鐙骨筋

他の部位の骨格筋線維に比し小径で筋線維の 数も少い.

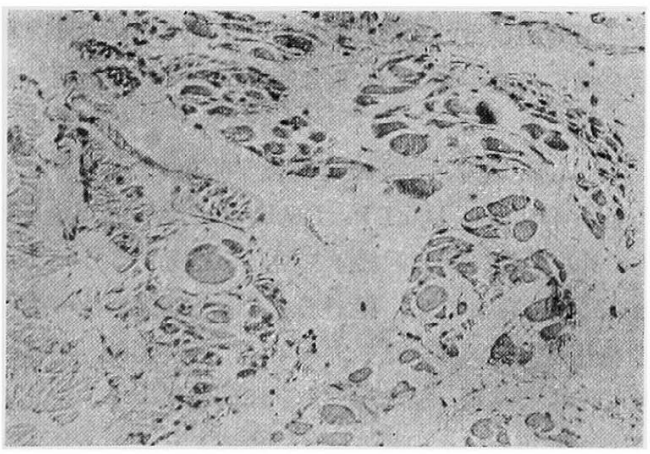

図 4 呈示した症例の鼓膜張筋

鐙骨筋と同様の筋線維の大小不同，变性消失 と結合織ならびに脂肪組織の増加が著明である。

変の程度はより軽度のようである.

図 2 は次挰示した症例の鐙骨能, 図 3 は正常者のも の，図 4 は症例の鼓膜張筋である.

\section{IV 症例}

D. M. P. Duchenne 型で恥力検查, 耳小骨筋の検索 後死亡, 剖検した症例を呈示する.

高○敏○16歳 男子

両親に血族結婚なし.母方叔父が D. M.P. で死亡し た. 同胞なし，妊娠および分婏飞特記すべき事なし，処 女歩行 1 歳 6 月, 3 歳頃家人により, 動摇性歩行, 歩行 が㢑い，転倒し易い，飛び上りができない等の歩行異常 が気付かれている， 7 歳 広大小児科にて D.M.P. の 㟝断を受け，直ちに国立療養所原病院筋ジストロフィー 症病棟に入院している.

入院時体格, 栄羙共中等度, 皮庵正常, 眼科, 耳鼻科 的飞異常所見なし，心肺腹部に特記することなし．腱反 射は両下肢共消失，上肢は減退，病的反射なし，歩行は 可能であるが脊柱の前弯，足関節の拘縮を認め，腓腹筋 の仮性肥大あり, 筋萎縮は腰, 䌓部, 下腿に著明, 血清 C.P.K 515，筋電図にて，筋原性のパターンを示す。

入院後歩行障害は漸次進行し, 9 歳歩行不能となり, 以後車椅子生活となる.

筋萎縮はその後全身骨格筋に著明となり, 脊柱の側弯, 胸廓の変形等も進行し，これに心筋のジストロフィーに よる病変が加わり, 心肺機能不全のため死亡した.

16歳の時施行した聴力検査では, 右耳 $125 \mathrm{~Hz} て ゙+5 \mathrm{db}$, $250 \mathrm{~Hz}$ で $+15 \mathrm{db}$, 左耳 $125 \mathrm{~Hz}$ で+25db，250Hzで +25 $\mathrm{db}$ と低音部の聴力低下を認めた（図 5).

耳小骨筋反射の所見では， $1 \mathrm{kHz}$ の刺激者で右耳 $\mathrm{T}_{1}$ $456 \mathrm{msec}, \mathrm{T}_{2} 448 \mathrm{msec}, \mathrm{T}_{3} 880 \mathrm{msec}$ で, 左耳 $\mathrm{T}_{1} 360$ msec, $T_{2} 380 \mathrm{msec}, \mathrm{T}_{3} 860 \mathrm{msec}$ で.正常者平均に比し 両耳共 $T_{3}$ の延長を認める（図 6)

病理学的所見では，全身骨格筋とくに近位筋に著明な 筋線維の消失と共飞, 心筋飞扣いても, 心筋線維の脱落 と線維化が，とくに左室に著明に認められた．

耳小骨筋では図 2,4，の如くで，他の 3 例のDuchenne 型に比し, 变化は強かった。

\section{考按}

耳小骨筋反射の聴覚における意義については, 耳小骨 筇の発見以来, 数多くの研究者の主題であったが, 未だ 決定的な結論はない。

耳小骨筋の機能については, Intensity control theory， Frequency selection theory, Labrynthine pressure theory, Fixation theory 等があるが, 現在では Protection theory をも含めた Intensity control theoryが 


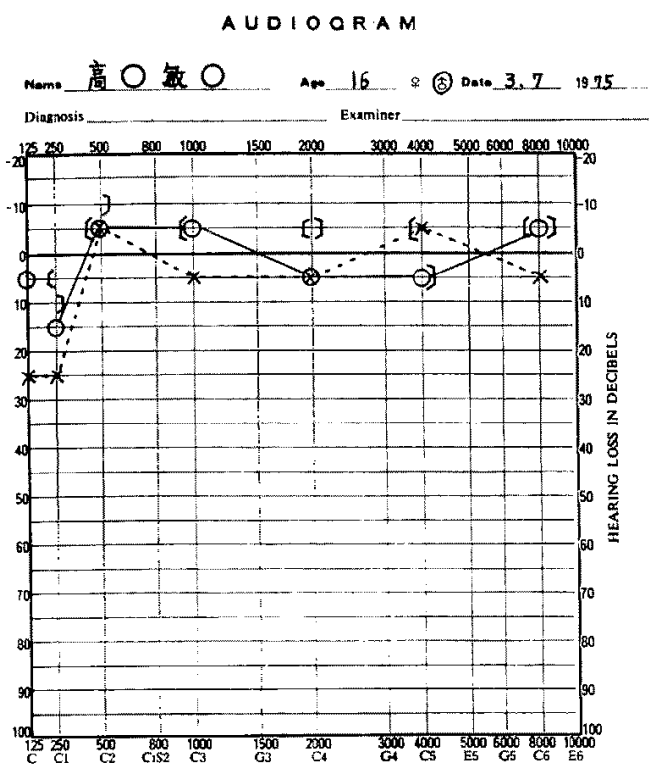

国 5
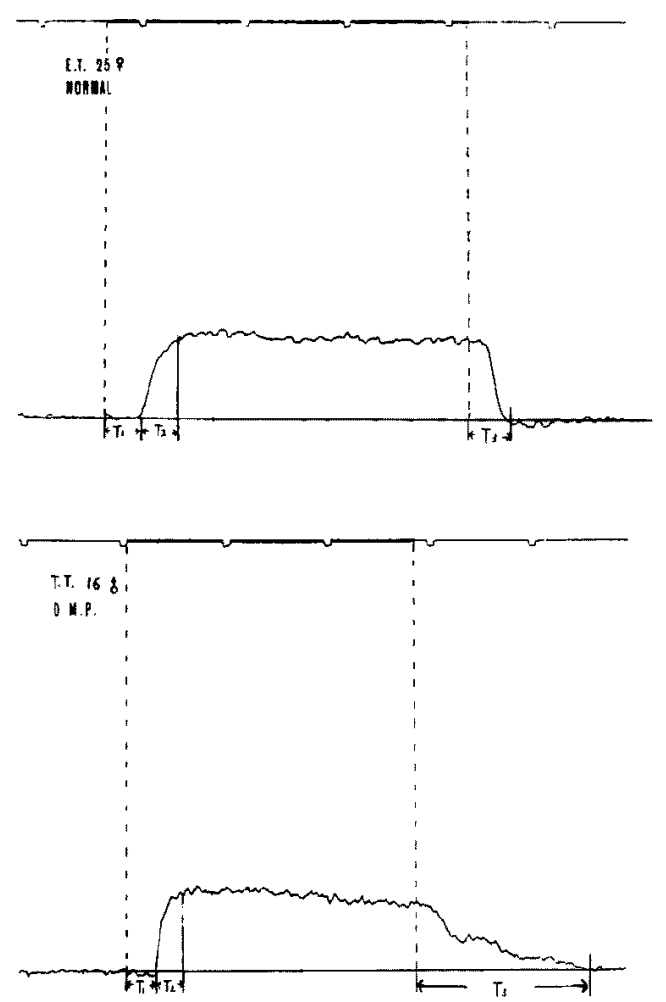

図 6 D.M.P.将例の耳小胃筋反身
一般的に支持されている.

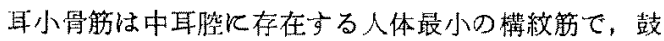
膜签筇，鐙骨筋の2筋よりなる。

これら雨筋が機能上それぞれどのような役割を担うか についてもまた多くの議諭のある所である，今回はその

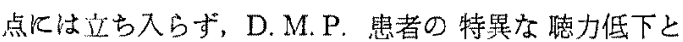
その意義及び耳小骨笳反射につき諭じたい。

D. M.P. 蛙佉性，家族性の疾患で，近位筋加占発 症，進行性飞全身横紋筇の変性消失飞至る疾患て，特飞 Duchenne 型は好児期化発病し，その進行は速く，20藏

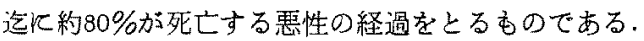

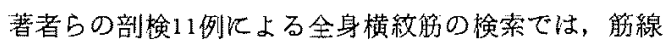
維の变性消失による残存筋実質は，四肢近位筋で5〜30\%

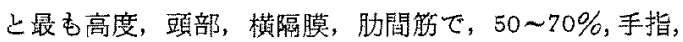
足部の筋で 50 80\%，舌筋，食道の横制筋では $75 \sim 90$ \%上最手轻加っだ。

D. M.P.に括いて，発病初期加 dystrophic な侵襲は当然考えられる所であるが, D.M.P. 剖検例に括ける耳小骨管の病理組織学的所見加らは，末 期飞执いても，他の骨格筋飞比し，その病変が楆めて軽 度であることを知り得た。

D. M.P. Duchenne 型患者の聴力検疽及ひ耳小骨筋 反射の検索は，生理的状態で，中耳伝音系の中で，耳小 学筋のみ選択的飞侵された状況での検查であり，これ迄 多数の研究者吕行った実駼動物飞外科的操作を加元たあ

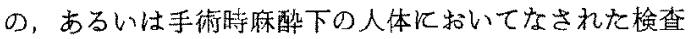
とは異った意義があると考光られる，

はじめK中耳疾患の既往のない，知能の正常な Duchenne 型 D.M.P.患者の気導聴力活いて，低音域の 㯖力損失を示するのの比率が，正常健康者に比し，高い 事或について考皇ると，一般低音域の聴力損失は，検 查烓の種々外的の条件怔考克られ，その断定には慎重を 要する所であるが，今回著者らの行った検査では，Dechenne 型患者と対照者とを同時に，同し条件で㭘査を 行ったものであり，同年齿の対照正常者にはこのような 結果を示さなかったことから意義があるとした。

更にこの低音域の聴力提失は Duchenne 型患者の中 でも，耳小骨筋の变化がより著明と考えられる高年粭者 群に乱いて，その発現の比率の扈いことに注目した。

G. Liden ${ }^{42}$ は Stapedectomy の患者加騷音下で会話 音の弁別能力の低下することを知り，鐙骨筋には，その 収縮により低音の螖牛入の伝達索低下させ，高音の聴力 を高めると考えている。 
Simmon \& Beatly ${ }^{52}$ は鐙骨筋の収縮飞より生ずる amplitude modulation が音の分析又注注意の維持を助 けるのではないる推祭している.

Smith \& Roger ${ }^{\theta)}$ ら估精神生理学的な実験で，耳小 骨筋の収縮は低周波数の音響の㯖党閾檤を上昇させると 報告している。

著者らは，D. M. P. Duchenne 型の僡力㭘敀の 結果 加ら，耳小骨筋に注，聞きとり難い程微弱な低音を，艺 の収縮によってよりよく聞き分ける作用があると推察し た.

生物界に却ける耳小骨筋の存在意義を考元るならぱ， 聴覚のもつ鋭敏性加らして，過大音響加ら内耳保護す る必要は当然考元占れ ，これ迄の耳小骨筋反射の実医 もその点を强調しているものが多い，人類出現期の自然 界飞郝けるこの上弓な過大音響は，火山の爆発，落雷等 比较的稀な現象であり，をしろ初期の人類にとり必要な ことは，自然の環境で外敵加ら身を守り，獲物の存在を

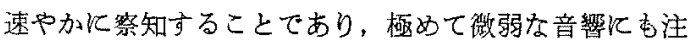
意を集中可る必要加ら，耳小骨缼加耳介之共にこの目的 で重要な僛きをなすことは肯ける所である.

次V D. M.P. Duchenne 型飞找ける耳小骨筋の機能 的变化は当然耳小骨筋反射の变化として湘定し得る笞で あり，この目的のために，著者らはインピーダンス法を 用いて，耳小骨筋反射検索した。

この検查に際して，患者らが身体的に衰㒉した状態に ある者が多いため，音響刺激として最高 90db 迄の純音 を使用し，耳小骨筋の疲労汇よる影餐を見るための反復 刺激に制限を加えざるを得なかった。

Duchenne 型飞括いては，年路が進むと共江䎲小骨筋 の dystrophic な变化も進行するものとの推測から，耳 小骨筋反射の成績を年龄別伙，轻，中等，重症の 3 群飞 分けて検討した.

潜伏期，刺激がはじまってから反射の振湢が最高飞達 する迄の時間では，予想に反し，正常群，各年龄群の間 飞著明な变化はなかったが刺激が終ってから耳小骨筋が 弛緩した状態腹する迄の時間では，重症群汇著明な延 長が認められた。この意義については，dystrophic 被 化を起している横敘笳の一般的な病態生理学的特性飞屯 とずくものであるうと解视している。

Duchenne 型飞格いても，耳小骨筋反射が正常者と殆 几ど变らず，平均 $75 \mathrm{db}$ 音篦刺激で出現する事尖は耳小 骨筇の病理組織学的所見加も明ら加なことく，その変 化が他の部位の横紋筇に比し，極めて柽いことによるも
ので，機能の低下として我々が予想した長時間の音響目 荷による易疲労性の確認は, 今回の䒠騃での負荷の程度 では, 重症群比招いて怪度の疲学飞上る变化加推測され た溜まった。

鼠後に Duchenne 型 D.M.P.の耳小骴㬳反射の臨床 的応用の可能性について言及したい。

日常臨床に招いて，D.M.P. 䁩者の筋力の消長を知る ために，筋力テスト，握力，歩行能力，四肢の挙上持続 時間等が検查されているが，これらは䞍神的底影響を受 け易く，純䊉に客観的なデータ一となり難い面がある。

これに反し，耳小管筋反射の際の刺激が終ってから，耳 小骨筋が旧の状態に復する迄の時間の变化を用いるなら ば，本人の意志汇かかわりなく，この筋の機能の变化を 推測し德る等である。

この値は，将来 D.M.P. K対し有效な薬剂が開発さ れた場合，その薬物の勃果判定の手段としても，筋生 検，筋電図検查と共に使用乙得る可能性がある。

\section{参考 文 献}

1) Metz $O$ : Studies on the contraction of the tympanic muscles as indicated by changes in the impedance of the ear. Acta Oto-laryngol. 39; $397-405,1951$.

2）中田将風：音䋨性耳小骨筋反射记関方る矿究 日耳 71; 34-47, 1978.

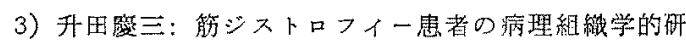
究 広島医学雑誌揭载子定

4) Liden $G$ et al. . Significance of the stapedius reflex for the understanding speech. Acta Otolaryngol. Suppl. 188; 275-279, 1963.

5) Simmons $F B$ et al.: Theory of middle ear muscle function at moderate sound level. Science 138, 590, 1962.

6) Smith $H D$ : Audiometric effect of voluntary contraction at the tensor tympanic muscle. Arch Otolaryngol. 38; 369, 1943 .

7) Reger $S N$ : Effect of middle ear muscle action on certain psychophysical measurements. Ann. Otol. 69; 1179, 1960.

8) Cancura $W$ : Der Einfluss der Binnenohrmuskulatur auf die Schalluibertragung in Mittelohr. Monatschr Ohrenheilk laryng Rhinol 104; 3, 1970,

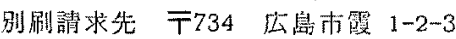
（原辢受付 昭和53，8，26日）

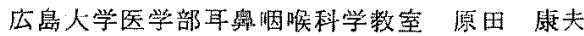

